\title{
Prevalence of and Risk Indicators for Chronic Periodontitis in Males from Campeche, Mexico
}

\section{Prevalencia de periodontitis crónica e indicadores de riesgo en hombres de Campeche, México}

Mirna Minaya-Sánchez ${ }^{1}$, Carlo E. Medina-Solís², Gerardo Maupomée , Ana A. Vallejos-Sánchez ${ }^{1}$, Juan F. Casanova-Rosado ${ }^{1}$ y María de L. Marquez-Corona²

1Facultad de Odontología Universidad Autónoma de Campeche. Campeche, México. 2 Instituto de Ciencias de la Salud Universidad Autónoma del Estado de Hidalgo. Pachuca, Hidalgo, México. cemedinas@yahoo.com

3 Oral Health Research Institute, Indiana University/Purdue University at Indianapolis School of Dentistry. Indianapolis, Indiana, USA.

Received $22^{\text {th }}$ January $2007 /$ Sent for Modification $29^{\text {th }}$ July 2007/Accepted $10^{\text {th }}$ August 2007

\begin{abstract}
Objective Determining the prevalence, severity and extension of chronic periodontitis and identifying risk indicators amongst policemen in Campeche, Mexico, using an electron probe.

Materials and Methods A cross-sectional study of a convenience sample of 161 men was conducted. A case of periodontitis was defined as a participant having clinical attachment loss in at least one $\geq 4 \mathrm{~mm}$ site. Every periodontal site in the mouth was measured by a standardized periodontist using a Florida Probe System. ${ }^{\text {TM }}$ STATA $8.2^{\mathrm{TM}}$ was used for bivariate and multivariate statistical analysis, using logistic binary regression.

Results Mean age was $38.36 \pm 10.99$ years. 23,622 periodontal sites were available for examination. Mean (SD) teeth and sites examined per person were $24.45 \pm 4.63$ and $146.72 \pm 27.80$, respectively. Periodontitis prevalence was $62.7 \%$. Periodontitis severity was $2.9 \mathrm{~mm}$ and extent was $53.7 \%$. Adjusted for alcohol intake, factors associated with periodontitis prevalence were being older ( $\geq 35$ years; OR $=2.08$; $\mathrm{CI} 95 \%=1.05-4.10)$, smoking (current/former; OR=2.22; CI95\%=1.06-4.77) and gingivitis (presence; OR=3.35; Cl95\%=1.34-8.42).

Conclusions Many study participants had poor periodontal conditions, with substantial overall prevalence of periodontitis. Older age, tobacco use and the presence of gingivitis were factors associated with periodontitis prevalence.
\end{abstract}

Key Words: Periodontal attachment loss, epidemiology, gingivitis, Mexico, periodontal disease, smoking (source: $M e S H, N L M$ ). 


\section{RESUMEN}

Objetivo Determinar la prevalencia, severidad y extensión de periodontitis crónica, e identificar indicadores de riesgo entre policías de Campeche, México, utilizando una sonda electrónica.

Material y Métodos Se realizó un estudio transversal en una muestra de conveniencia de 161 hombres. Un caso de periodontitis fue definido como pérdida de inserción en al menos un sitio $\geq 4 \mathrm{~mm}$. Todos los sitios periodontales fueron medidos utilizando la sonda Florida Probe System ${ }^{\mathrm{TM}}$ por un periodoncista estandarizado. Los análisis bivariado y multivariado fueron realizados en STATA 8.2 utilizando regresión logística binaria.

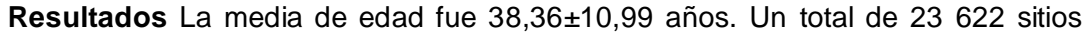
periodontales estuvieron disponibles para examen. El promedio de dientes y sitios examinados por persona fue $24,45 \pm 4,63$ y $146,72 \pm 27,80$, respectivamente. La prevalencia de periodontitis fue $62,7 \%$. La severidad fue de $2,9 \mathrm{~mm}$ y la extensión fue $53,7 \%$. Ajustando por consumo del alcohol, los factores asociados a la prevalencia fueron mayor edad ( 235 años; RM=2,08; IC95 \%=1,05-4,10), tabaquismo (actual y pasado; RM=2,22; IC95 \%=1,06-4,77), y gingivitis (presencia; RM=3,35; Cl95 \%=1,34-8,42).

Conclusiones La mayoría de los participantes tuvieron una condición periodontal desfavorable. La mayor edad, el uso de tabaco y la presencia de gingivitis fueron variables asociadas con la prevalencia de periodontitis.

Palabras Clave: Pérdida de inserción peridontal, epidemiología, gingivitis, México, enfermedades periodontales, tabaquismo (fuente: DeCS, BIREME).

$\mathrm{O}$ ral diseases represent a common public health problem in Mexico, dental caries $(1,2)$ and periodontal diseases (3) being the most prevalent. Periodontal diseases are a group of infectious diseases affecting the tissues supporting the teeth, having common clinical manifestations (chronic inflammation). These diseases are assumed to be associated with pathogenic bacteria specifically colonising subgingival regions (4) and are said to result from the complex interaction between bacterial infection and host response, modified by environmental factors (5). The severity of periodontal diseases varies over time, depending on the quantity and quality of the biofilm and the presence of factors modifying the permanence of plaque (6). Chronic periodontitis may affect one or several periodontal sites within the mouth, leading to different levels of tissue destruction (7); this is preceded by gingivitis (8) and is often demonstrated by measuring periodontal ligament clinical attachment loss (CAL).

Although oral microorganisms seem to play a preponderant role in the aetiology of chronic periodontitis (9), other risk indicators have been identified. Chronic 
periodontitis has been considered to be more common in people aged more than 30, having inadequate oral hygiene $(10,11)$ and/or high levels of stress (12). Its distribution is also associated with smoking $(13,14)$ and low socioeconomic status (LSS) (15). In addition to these socio-demographic, socioeconomic, and behavioral factors, other factors have been mentioned in association with chronic periodontitis (3,10,16-18). Few studies have documented the distribution of chronic periodontitis and its determinants in Mexico, including those related to its prevalence, severity, extension, and risk factors (3). The present study was aimed at determining the prevalence of chronic periodontitis, its severity and extension and characterizing the factors associated with it in adult males in the city of Campeche, Mexico.

\section{MATERIAL AND METHODS}

Study design and subject selection

This study complied with specifications for protecting study participants and adhered to the Universidad Autónoma de Campeche's ethical regulations (being the state public university in Campeche, Mexico). This was a cross-sectional study carried out on a non-probabilistic sample of police officers from the city of Campeche. Inclusion criteria consisted of being male, older than 20 and having at least 6 natural teeth in the mouth. Exclusion criteria were edentulous individuals, individuals whose ability to open the mouth impeded a clinical exam, individuals undergoing periodontal treatment and individuals currently taking antibiotics. After obtaining informed consent, the total sample consisted of 161 male subjects.

Data collection

Subjects were examined in a dental chair. Clinical variables were evaluated by a periodontist (kappa $>0.60$ ) using a computerised periodontal probe (Florida Probe ${ }^{\circledR}$ - Florida Probe Corp. Gainesville FL) (19) having a $0.45 \mathrm{~mm}$ tip diameter. Probe precision level was $0.2 \mathrm{~mm}$ with regulated 15 gram pressure. Six sites were evaluated (distobuccal, midbuccal, mesiobuccal, distolingual, midlingual and mesiolingual) on each available tooth per subject, except for third molars (maximum 168 sites/subject). Periodontitis, dental plaque, dental calculus, gingival bleeding, suppuration and number of teeth present were recorded. A questionnaire was used for obtaining information re age, marital status, educational level, frequency of tooth brushing, tobacco and alcohol intake, antibiotic use during the previous six months and use of dental care during the previous year. A subject was considered to be a current cigarette smoker if he 
had smoked at least 20 cigarettes/week during the previous six months. Alcohol consumption was considered positive if the subject reported at least one drink per week for the previous six months.

The dependent variable was periodontitis; it was operationally based on CAL. A subject had to have had at least one $\geq 4 \mathrm{~mm}$ CAL site to meet the criteria for a periodontitis case. Periodontitis prevalence was the percentage of subjects having at least one $\geq 4 \mathrm{~mm}$ CAL site. Severity was the amount of CAL at affected sites, while extension described the proportion of a subject's sites having periodontitis (20).

Data analysis

Univariate analysis gave a summary of measurements according to variable measurement scale. Bivariate analysis then used binary logistic regression, reporting odds ratio (OR), $95 \%$ confidence interval (95 \% CI) and p-value. The final multivariate model was constructed by including variables if they had $\mathrm{a}<0.30 \mathrm{p}$ value in bivariate analysis. All possible interactions between variables in the final model were evaluated. Variance inflation factor (VIF) test evaluated multi-colineality (and for avoiding it, if present). The Box-Tidwell test was applied to see whether a continuous independent variable should remain as such in the final model (i.e. the probability of having periodontitis had the same magnitude for every unit increase in age). Age was divided into $<35$ years and $\geq 35$ years as it did not comply with such assumption. Pearson's Goodness of Fit test was applied to the final model to evaluate whether observed probabilities were different to estimated probabilities (21).

\section{RESULTS}

Table 1 shows univariate results. 161 subjects were examined (38.36 \pm 10.99 mean (SD) age; 20-78 range). Average schooling was $10.05 \pm 2.26$ years (3-17 range), most subjects having gone on to secondary education (9 years' schooling). 93,8 \% reported that they brushed their teeth at least once a day; $39,8 \%$ indicated that they smoked regularly, $46 \%$ reported consuming alcohol and 19,9\% reported having used antibiotics during the past six months.

The mean of teeth present in the mouth was $24.45 \pm 4.63$ (6-28 range). Regarding dental visits, 91,9\% of the policemen reported having made at least one visit within the past year (the reasons for visits were not investigated, so they could have been emergencies or routine visits). The following results were obtained regarding extensive oral conditions (arbitrary cut-off set at $\geq$ 
$20 \%$ of dental surfaces): 73,9 \% plaque, 47,8 \% calculus, 21,7 \% having sites with suppuration and $83,9 \%$ had periodontal sites with gingivitis. Periodontitis prevalence was $62,7 \%$. Mean periodontitis severity was $2,9 \mathrm{~mm}$ and the extent (percentage of affected periodontal sites) was 53,7 \%. 83,9\% of the subjects presented at least one $\geq 3 \mathrm{~mm}$ probing pocket depth while 77,6 \% presented at least one site having $\geq 4 \mathrm{~mm}$ probing pocket depth.

Table 1. Description of the independent variables included in the study $(n=161)$

\begin{tabular}{|c|c|c|}
\hline Variable & & Mean \pm SD \\
\hline Mean age & & $38,36 \pm 10.99$ \\
\hline Mean maximum level of schooling & & $10,05 \pm 2.26$ \\
\hline Mean number of teeth & & $24,45 \pm 4.63$ \\
\hline & Frequency & Percentage \\
\hline $\begin{array}{l}\text { Marital status } \\
\text { Single } \\
\text { Cohabitating }\end{array}$ & $\begin{array}{c}25 \\
136\end{array}$ & $\begin{array}{l}15,5 \\
84,5\end{array}$ \\
\hline $\begin{array}{l}\text { Dental care during previous } \\
\text { months } \\
\text { No } \\
\text { Yes }\end{array}$ & $\begin{array}{c}12 \\
13 \\
148\end{array}$ & $\begin{array}{c}8,1 \\
91,9\end{array}$ \\
\hline $\begin{array}{l}\text { Tooth brushing frequency } \\
<1 / \text { day } \\
\text { At least } 1 \text { day }\end{array}$ & $\begin{array}{c}10 \\
151\end{array}$ & $\begin{array}{c}6,2 \\
93,8\end{array}$ \\
\hline $\begin{array}{l}\text { Tobacco use } \\
\text { Never } \\
\text { Formerly } \\
\text { Current }\end{array}$ & $\begin{array}{l}52 \\
45 \\
64\end{array}$ & $\begin{array}{l}32,3 \\
27,9 \\
39,8\end{array}$ \\
\hline $\begin{array}{l}\text { Alcohol intake } \\
\text { Never } \\
\text { Formerly } \\
\text { Current }\end{array}$ & $\begin{array}{l}23 \\
64 \\
74\end{array}$ & $\begin{array}{l}14,3 \\
39,7 \\
46,0\end{array}$ \\
\hline $\begin{array}{l}\text { Use of antibiotics in past } 6 \text { months } \\
\text { No } \\
\text { Yes }\end{array}$ & $\begin{array}{c}129 \\
32\end{array}$ & $\begin{array}{l}80,1 \\
19,9\end{array}$ \\
\hline $\begin{array}{l}\text { Presence of dental plaque } \\
\text { Without } \\
\text { With }\end{array}$ & $\begin{array}{c}42 \\
119\end{array}$ & $\begin{array}{l}26,1 \\
73,9\end{array}$ \\
\hline $\begin{array}{l}\text { Presence of calculus } \\
\text { No } \\
\text { Yes }\end{array}$ & $\begin{array}{l}84 \\
77\end{array}$ & $\begin{array}{l}52,2 \\
47,8\end{array}$ \\
\hline $\begin{array}{l}\text { Presence of suppuration } \\
\text { No } \\
\text { Yes }\end{array}$ & $\begin{array}{c}126 \\
35\end{array}$ & $\begin{array}{l}78,3 \\
21,7\end{array}$ \\
\hline $\begin{array}{l}\text { Presence of gingivitis } \\
\text { No } \\
\text { Yes }\end{array}$ & $\begin{array}{c}26 \\
135\end{array}$ & $\begin{array}{l}16,2 \\
83,9\end{array}$ \\
\hline
\end{tabular}

Maximum level of schooling was similarly distributed between those presenting periodontitis or not (Mann-Whitney, $\mathrm{p}>0.05$ ). Table 2 gives the results of bivariate analysis between periodontitis and each independent variable. 
Maximum schooling level, marital status, antibiotics use, number of teeth present, tooth brushing pattern, presence of periodontal suppuration and tobacco use all had p-values above 0.05 . The variable having the greatest association with the presence of periodontitis was gingivitis ( $\mathrm{OR}=2.72$; 95\%CI=1.16-6.42).

Table 2. Bivariate analysis of logistical regression between periodontitis ( $0=$ subjects without periodontitis, $1=$ subjects having periodontitis)

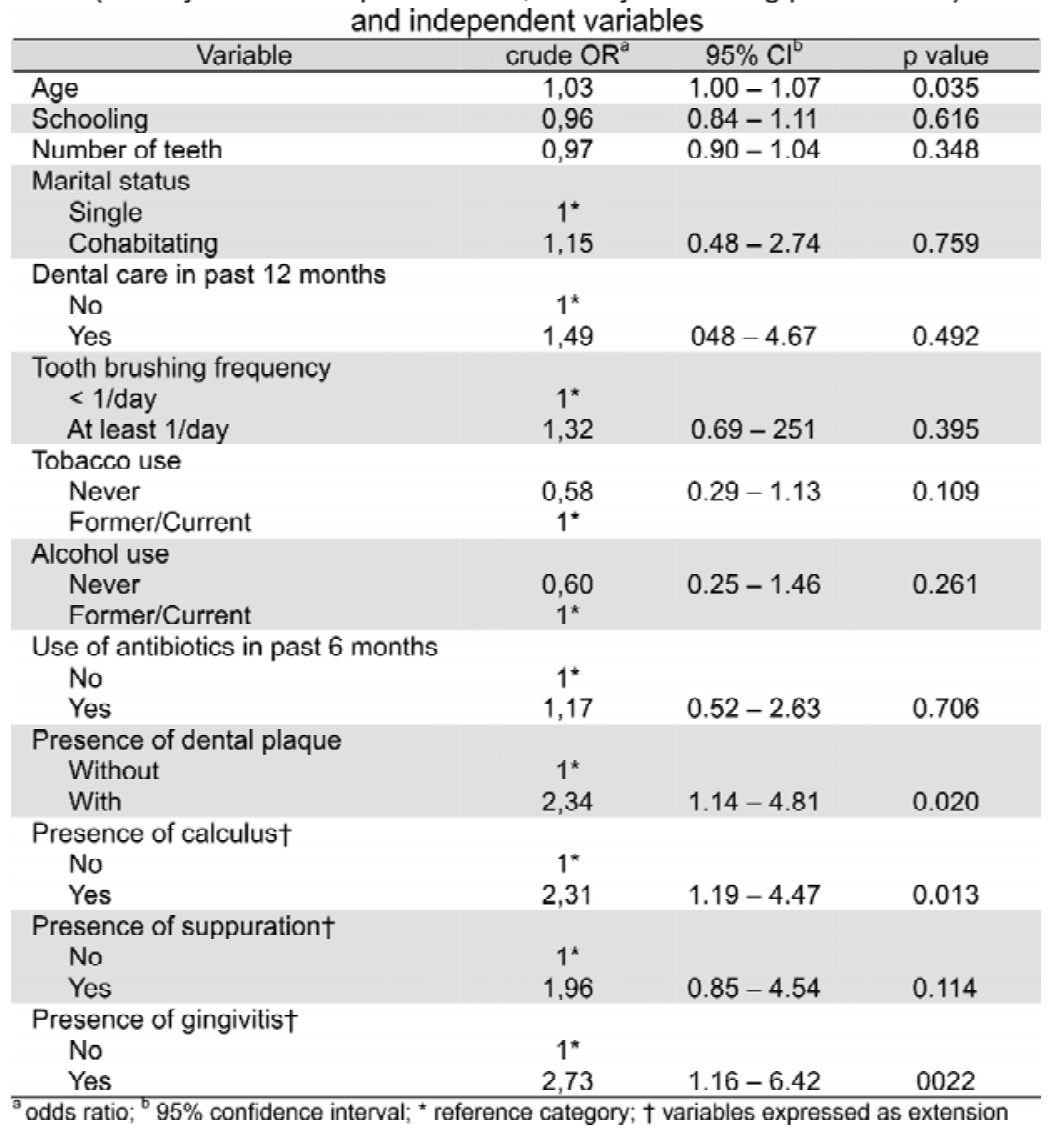

Multivariate analysis

Adjusting for alcohol use, subjects aged $\geq 35$ had a greater probability $(\mathrm{OR}=2,08$; $95 \% \mathrm{CI}=1.15-4.10)$ of presenting periodontitis than subjects aged younger than 35. Likewise, the odds of periodontitis ocurring in subjects currently or previously using tobacco was greater $(\mathrm{OR}=2,22 ; 95 \% \mathrm{CI}=1.06-4.77)$ than the odds of 
those who had never smoked. The possibility of subjects with gingivitis having periodontitis was 3,35 times (95\% CI=1.34-8.42) than in those classified as not having gingivitis (Table 3 ).

Table 3. Multivariate logistical regression model between periodontitis ( $0=$ subjects without periodontitis, $1=$ subjects having periodontitis)

\begin{tabular}{|c|c|c|}
\hline Variable & OR $(95 \% \mathrm{CI})^{a}$ & $p$ value \\
\hline \multicolumn{3}{|l|}{ Age } \\
\hline$<35$ & $1^{*}$ & \\
\hline$\geq 35$ & $2,08(1,05-4,10)$ & 0.035 \\
\hline \multicolumn{3}{|l|}{ Tobacco use } \\
\hline Never & $1^{*}$ & \\
\hline Former/Current & $2,22(1,06-4,77)$ & 0.035 \\
\hline \multicolumn{3}{|l|}{ Presence of gingivitis } \\
\hline No & $1^{*}$ & \\
\hline Yes & $3,35(1,34-8,42)$ & 0.010 \\
\hline
\end{tabular}

\section{DISCUSSION}

Many subjects presented with unfavourable periodontal conditions. Older age, tobacco use and gingivitis were factors associated with increased periodontitis prevalence. Current understanding of some sequels of chronic destructive periodontal diseases suggests that this status could have serious implications for oral and systemic health. While periodontitis has an impact on oral function, orofacial appearance and oral health-related quality of life, it may also be associated with inflammation, bleeding and suppuration. Due to possible oralsystemic linkage, periodontal conditions may be implicated in the increased risk of diverse systemic disease (22) and (not being directly related to our study population) even lead to suggestions of having an aetiological role in premature birth and low birth weight (23).

Periodontitis prevalence ( $\geq 1$ site having $\geq 4 \mathrm{~mm}$ CAL) observed in the male population being studied was consistent with other studies. Our findings can be compared within Latin-America (few existing studies) with a Brazilian study on adults aged 30 to $103 ; 97,4 \%$ prevalence of individuals having $\geq 3$ mm CAL and $92,9 \%$ and $79,2 \%$ for $\geq 4 \mathrm{~mm}$ and $\geq 5 \mathrm{~mm}$ CAL, respectively, were reported (10). Comparing our results to reports from industrialised nations suggests that prevalence figures were similar. Albandar (16) has reported 53,1 $\% \geq 3 \mathrm{~mm}$ CAL prevalence in 30 to 90 year-old American adults. They evaluated two quadrants and two sites per tooth (mesiobuccal and midbuccal). $\geq 3 \mathrm{~mm}$ pocket depth prevalence was 63,9\%. Locker and Leake reported 88 
$\% \geq 4$ mm CAL prevalence in a 50+ year-old Canadian population (24). Direct comparisons with these prevalence figures led to caveats and cautionary remarks, as case criteria may be $\geq 3 \mathrm{~mm}, \geq 4 \mathrm{~mm}$ or $\geq 5 \mathrm{~mm}$ CAL, partial or full-mouth measurements may be used for estimating disease (which may be problematic, as the former can mask true periodontitic prevalence) (25) and studies may include different age groups.

Our multivariate analysis findings confirmed association between chronic periodontitis and some clinical and socio-demographic variables. Periodontal disease is an oral disease having cumulative characteristics so that sequels are more easily identified in older age groups $(13,26)$. The present study showed that age is an important factor associated with worse CAL; 54,9 \% of subjects aged younger than 35 met case definition, whereas $68,9 \%$ of $35+$ year-olds did so. These results are consistent with other studies which found that periodontitis prevalence increased as age increased $(10,11)$.

Our results were also consistent with studies by Susin (Brazil) (14) and Hayman and Red (North America) (13) who reported that tobacco consumption had an important effect on periodontitis prevalence and that there was a doseresponse effect between smoking and periodontal disease. A causal relationship cannot be ascribed as most studies demonstrating the relationship between tobacco use and periodontal disease are cross-sectional. The exact mechanism by which tobacco use causes periodontal disease remains unknown. As it can act in various dimensions, diverse mechanisms are possible, including speculation that the interface between smoking and signs/symptoms of inflammation are nicotine-mediated/modified (37).

Although it is known that gingivitis does not unavoidably advance to periodontitis, it is also known that periodontitis does not exist without prior gingivitis (8). Our findings support such association between gingivitis and periodontitis (17) for both early stages and for moderate and advanced periodontitis $(16,18)$.

The present study has limitations which should be taken into account when interpreting the results. Some independent variables were collected through questionnaires which, even though commonly used in research, can introduce bias (an obvious example being self-reported tooth brushing frequency, which was difficult to reconcile with clinical findings). We believe, however, that tobacco use is quite reliable, as smoking has nowhere near the same health stigma in Mexico as it has in the USA today. Our study design implied temporal 
ambiguity as cross-sectional approaches simultaneously measure cause and effect.

Despite similar findings to other populations being obtained, we did not use a random sample. Our study's strengths lie in the study population's relative homogeneity of career, lifestyle and socioeconomic background, the inclusion of all periodontal sites of all teeth present and using an electron probe (being consistently more reliable than the manual probes used in other studies). The electron probe is less liable to suffer from examiner error. Whilst using an electron probe made data collection more cumbersome than with a manual probe, this is the first study of its kind in Latin-America allowing for such precision in clinical measurements.

The present study has thus documented determinants of chronic periodontitis in a homogenous study-group in Mexico who often presented poor periodontal conditions. Older age, tobacco use and having gingivitis were factors associated with higher periodontitis prevalence

Acknowledgments. This work was partially funded by a grant from the Universidad Autónoma de Campeche for the main author to obtain an MSc. The analysis of this work was also partially supported by the Mexican National Council of Science and Technology(CONACyT-166266).

\section{REFERENCES}

1. Casanova-Rosado AJ, Medina-Solís CE, Casanova-Rosado JF, Vallejos-Sánchez AA, Maupomé G, Ávila-Burgos L. Dental caries and associated factor in Mexican schoolchildren aged 6-13 years. Acta Odontol Scand 2005;63:245-51.

2. Medina-Solis CE, MaupoméG Pelcastre-Villafuerte B, Avila-Burgos L, Vallejos-Sánchez AA, Casanova-Rosado AJ. Socioeconomic inequalities in oral health: dental caries in 6 to 12 year-old children. Rev Invest Clin 2006;58:296-304.

3. Borges-Yanez SA, Irigoyen-Camacho ME, Maupome G. Risk factors and prevalence of periodontitis in community-dwelling elders in Mexico. J Clin Periodontol 2006;33:184-94.

4. Genco RJ. Current view of risk factors for periodontal diseases. J Periodontol 1996;67(Suppl):1041-9.

5. Fenesy KE. Periodontal disease: an overview for physicians. Mt Sinai J Med 1998;65:3629.

6. Kornman KS. Nature of periodontal diseases: Assessment and diagnosis. JPeriodontal Res 1987;22:192-204. 
7. Socransky SS, HaffejjeAD. Microbial mechanisms in the pathogenesis of destructive periodontal diseases: a critical assessment. J Periodontal Res 1991;26:195-212.

8. Löe H, Anerud A, Boysen H, Smith M. The natural history of periodontal disease in man. Study design and baseline data. J Periodontal Res 1978;13:550-62.

9. Tanner ACR, Maiden MF, Macuch PJ, Murray LL, Kent RL Jr. Microbiota of health, gingivitis, and initial periodontitis. J Clin Periodontol 1998;25:85-98.

10. Susin C, Dalla Vecchia CF, Oppermann RV, Haugejorden O, Albandar JM. Periodontal attachment loss in an urban population of Brazilian adults: effect of demographic, behavioral, and environmental risk indicators. J Periodontol 2004;75:1033-41.

11. Krustrup U, Petersen PE. Periodontal conditions in 35-44 and 65-74-year-old adults in Denmark. Acta Odontol Scand 2006;64:65-73.

12. Akhter R, Hannan MA, Okhubo R, Morita M. Relationship between stress factor and periodontal disease in a rural area population in Japan. Eur J Med Res 2005;10:3527.

13. Hyman JJ, Reid BC. Epidemiologic risk factors for periodontal attachment loss among adults in the United States. J Clin Periodontol 2003;30:230-7.

14. Susin C, Oppermann RV, Haugejorden O, Albandar JM. Periodontal attachment loss attributable to cigarette smoking in an urban Brazilian population. J Clin Periodontol 2004;31:951-8.

15. Borrell LN, Beck JD, Heiss G. Socioeconomic disadvantage and periodontal disease: the Dental Atherosclerosis Risk in Communities study. Am J Public Health 2006;96:332-9.

16. Albandar JM, Kingman A. Gingival recession, gingival bleeding, and dental calculus in adults 30 years of age and older in the United States, 1988-1994. J Periodontol 1999;70:30-43.

17. Tanner AC, Kent R Jr, Van Dyke T, Sonis ST, Murray LA. Clinical and other risk indicators for early periodontitis in adults. J Periodontol 2005;76:573-81.

18. Haffajee AD, Socransky SS, Lindhe J, Kent RL, Okamoto H, Yoneyama T. Clinical risk indicators for periodontal attachment loss. J Clin Periodontol 1991;18:117-25.

19. Gibbs CH, Hirschfeld JW, Lee JG Low SB, Magnusson I, Thousand RR, et al. Description and clinical evaluation of a new computerized periodontal probe--the Florida probe. JClin Periodontol 1988;15:137-44.

20. Carlos JP, Wolfe MD and Kingman A. The extent and severity index: a simple method for use in epidemiologic studies of periodontal disease. J Clin Periodontol 1986;13:500-5.

21. BagleySC, WhiteH, GolombBA. Logistic regression in the medical literature: Standards for use and reporting, with particular attention to one medical domain. J Clin Epidemiol 2001;54:979-85. 
22. Dietrich T, Garcia RI. Associations Between Periodontal Disease and Systemic Disease: Evaluating the Strength of the Evidence. J Periodontol 2005;76:2175-84.

23. Khader YS, Ta'ani Q. Periodontal diseases and the risk of preterm birth and low birth weight: a meta-analysis. J Periodontol 2005;76:161-5.

24. Locker D, Leake JL. Periodontal attachment loss in independently living older adults in Ontario, Canada. J Public Health Dent 1993;53:6-11.

25. Borges-Yáñez SA, Maupomé G, Jiménez-García G. Validity and reliability of partial examination to assess severe periodontitis. J Clin Periodontol 2004;31:112-8.

26. Medina-Solis CE, Pérez-Núñez R, Maupomé G, Casanova-Rosado JF. Edentulism among Mexicans 35 years old and older, and associated factors. Am J Public Health 2006;96:1578-81.

27. Bergstrom J. Tobacco smoking and chronic destructive periodontal disease. Odontology 2004;92:1-8. 